UDC: 821.111.09-31 Велс Х. Џ.

\title{
- THE SPATIAL CONTINUATION OF ENGLISHNESS IN H. G. WELLS'S MEN LIKE GODS ${ }^{1}$
}

\author{
MAXIM SHADURSKI ${ }^{2}$ \\ University of Edinburgh, \\ School of Literatures, Languages and Cultures, \\ Department of English Literature, Edinburgh, UK
}

Rad analizira kontinuitet i diskontinuitet između Engleske i Utopije u romanu H. G. Velsa Ljudi poput bogova (1923). Odredivši mogućnost putovanja kroz vreme, Vels osnažuje ideju da Utopija može biti produžetak Engleske u prostoru.

Ključne reči: utopija, Engleska, nacionalni identitet, prostorni kontinuitet, entropija.

\section{INTRODUCTION}

Herbert George Wells (1866-1946) was preoccupied with the ideas of progress and gradual evolution. They were, in Laura Marcus's estimation, "substantially based on the admixture in his work and thought of experiments with time and histories of mankind" (Marcus 2007: 58). In his utopian novel Men Like Gods (1923), Wells steers the weary and somewhat neurasthenic protagonist Mr Barnstaple into a future which negates the implausibility of progress. Like the protagonist of The Time Machine (1895), Barnstaple accelerates into a history set in the same spatial realm as contemporary England, only in another temporal dimension. Yet on closer examination, Utopia contains a number of crucial openings which help to reduce the conceptual distance between Englishness and the Utopian identity. This paper examines continuities and ruptures between England and Utopia on the level of spatiality in Men Like Gods. My central contention is that Utopia is derived from England's landmarks and constitutes the spatial continuation of Englishness.

1 The research for this article was funded by the University of Edinburgh and a Scottish Overseas Research Scholarship (SORSAS). I wish to express my gratitude to Dr Anna Vaninskaya of the University of Edinburgh for her helpful suggestions and constructive feedback on this paper.

2 Kontakt podaci (Email): M.Shadurski@sms.ed.ac.uk 


\section{BIFOCAL PERSPECTIVE ON ENGLAND}

In Men Like Gods, England's spatial continuation unveils itself, for the most part, between the traveller's departure and return. Making his way to "Elsewhere" in a motor car, Barnstaple registers the regularities of a London morning with its lively traffic, and of the English countryside, once he has moved out of Sydenham and Slough: "A conspicuous feature in this tranquil landscape was the board advertisement of a riverside hotel at Maidenhead" (Wells 1923: 14). The intrusion of commercialism into an idyllic England, where nature mingles with houses and is presided over by Windsor Castle, signals a disparity between age-long and temporary features of the landscape. This dissonance is enhanced further after the protagonist's return from Utopia with a notably transformed mode of perception: "This old world seemed to him to be full of unlovely sights and sounds and odours already half forgotten" (Wells 1923: 296). Barnstaple perceives the once familiar landscape through the prism of more pleasing and orderly landmarks that Utopia has offered him. But it is not so much the landscape that he finds deficient on his return, but the disarray of man's livelihood inflicted upon it.

Such a bifocal perspective on England is grounded in Wells's other writings. Wells often portrayed England with a touch of sentimentality and irony, making her figure as a land of curiosities. Even the air and the sun feel different in London than elsewhere when noticed by the eponymous heroine of Ann Veronica (1909), "the soft sunshine of London, the softest, the finest grained, the most penetrating and least emphatic sunshine in the world" (Wells 1920: 82). "Joie de vivre" initially reigns in The History of Mr Polly (1910), in an England of "pleasant breezes and songbirds and shady trees" (Wells 1982: 32). England's quaintness comes alive due to a deep sense of the past which an American visitor discerns in Mr Britling Sees It Through (1916) and compares seeing England with "travelling in literature" (Wells 1933: 10).

Wells also authored less compromising visions of England, frequently marked by decay and doomed to destruction. In Patrick Parrinder's words, Tono-Bungay (1909) presented "an allegory suggesting England's dissolution" (Parrinder 2006: 305). This "Condition of England" is magnified through the lens of a fragmented London, starting in the "dignified places" of Westminster, then moving to the "heart of the world" along the Embankment, and exhausting itself near the sea, "beyond all law, order, and precedence" (Wells 2010a: 348-50). What adds to the effect of dissolution is the reduction of the national identity to "a set of unsustainable consumer practices" (Kupinse 1999: 70), turning England into a commodity which will inevitably go to waste: "The river passes - London passes, England passes..." (Wells 2010a: 352). The dissolution of England is taken a step further in some of Wells's scientific romances in which he unleashes his "relish for destruction" (Parrinder 1970: 34). An alien invasion of the country is carried out in The War of the Worlds (1898) when a nearly invincible horde of Martians, in search of a better habitat, wipes out human civilization without a second thought, and London looms as "a city condemned and derelict" (Wells 1975: 175). It is hardly surprising that the protagonist of When the Sleeper Wakes (1899) feels bewildered and hesitantly inquires: "Is there England still? That's a comfort! Is there London?" (Wells 2003: 29). However, very little remains of London, the epitome of the old world, in Wells's apocalyptic novel In the Days of the Comet (1906): "Where is London, 
that sombre city of smoke and drifting darkness, full of the deep roar and haunting music of disorder..." (Wells 19--: 220-21).

Consequently, as far as England and Englishness are concerned, Wells's position appears somewhat redolent of his war-time character Mr Britling, in whom he saw an embodiment of his own type and class (Wells 1934: 670). Mr Britling "was proud of England and abused her incessantly" (Wells 1933: 28). Such an ambivalent relationship with England may be said to oscillate between patriotic attachment and rational rejection. On closer look, England rarely becomes the target of elimination for its own sake; instead, want and depravity of its dismal condition are subjected to erasure in order to make room for a new order. In a similar fashion, the main character of Men Like Gods is relocated from England to Utopia, noticing a few significant changes: "This was an entirely different road from the one he had been upon half a minute before. The hedges had changed, the trees had altered, Windsor Castle had vanished, and a small compensation - the big Limousine was in sight again" (Wells 1923: 15). This seemingly continuous progression, in which nature has undergone transformations, obliterates a crucial aspect of Englishness - the symbol of its monarchy. Windsor Castle will undoubtedly re-emerge on Barnstaple's return to England. But originally Barnstaple may sense that it was as irrelevant in Utopia as the Limousine with other Earthlings whose identity will later turn out to be at variance with the whole concept of Utopia.

\section{TOPOGRAPHIC HOMOLOGIES AND CONTRASTS BETWEEN ENGLAND AND UTOPIA}

The topography of England and Utopia in Men Like Gods suggests homologies with John Bunyan's The Pilgrim's Progress (1678). Like Christian, who dreams of finding a way from the City of Destruction to the Celestial City, Barnstaple heads from London to Utopia. The road leading there passes through Slough, while the Celestial City can be reached by overcoming the Slough of Despond (Bunyan 2008: 17). Aside from this "roadmap", Wells does not offer any further deliberation about Slough, but it may be contextualized in Barnstaple's response to the somewhat grim reality of England, overshadowed by "commercial ruin", "unforgettable and unforgivable outrages" in Ireland, a prolonged drought (Wells 1923: 5), which create an atmosphere of despond. To Christian, the Slough of Despond looks like a "particularly filthy ground", arousing "in his soul many fears and doubts, and discouraging apprehensions" (Bunyan 2008: 18). The homologous idea behind the journeys of Christian and Barnstaple is teleological, deeply rooted in Christian symbolism. As John Gray has noted, "theories of progress are not scientific hypotheses. They are myths, which answer the human need for meaning" (Gray 2007: 2). Indeed, the two characters' progress takes them out of despond and brings them, with a varying degree of effort and revelation, to what they perceive as a more hopeful stage. As a matter of fact, Barnstaple distinguishes paradisiacal qualities in Utopia in "groups and clusters of flowerlike buildings", and "paths and steps and pools of water as if the whole place were a garden" (Wells 1923: 37).

The paradisiacal qualities also manifest themselves in the physical clearness of Utopia. Not only is the road to Utopia made of glass, and the air is clear and full of 
sweetness, but the sky and water are also crystalline there (Wells 1923: 16, 17, 154). In a way, England has almost completely shrunk from view in such warmer transparent climes, reminiscent of an area "beyond the Alps", to which Wells referred in A Modern Utopia (Wells 1967: 13). However, something very precious, in the eyes of the Earthlings, has been sacrificed on the altar of clearness. Taking a critical line, Mr Rupert Catskill, one of the novel's characters, admits: "Life on earth was... insecure, full of pains and anxieties, full indeed of miseries and distresses and anguish, but also, and indeed by reason of these very things, it had moments of intensity, hopes, joyful surprises, escapes, attainments, such as the ordered life of Utopia could not possibly afford" (Wells 1923: 91-92). The lack of anxieties, insects and even swallows in Utopia, highlights a divide separating Englishness from the Utopian identity. Whenever such a split is gauged, there appears very little cohesion between the atmosphere of turmoil, from which the Earthlings have emerged, and Utopian clearness, which has arisen as a result of progress. The fact that the Utopians organize a conference to discuss "the Age of Confusion" predating their own existence by several thousand years evokes an episode from William Morris's News from Nowhere (1891). People of "the epoch of rest" commemorate "The Clearing of Misery" by letting young ladies sing of want and suffering that afflicted the previous period. On hearing one such song, Guest's interlocutor exclaims, "a tragedy [has] grown inconceivable to her and her listeners. <...> [H]ow glorious life is grown!" (Morris 2003: 57).

The testimony to "glorious" improvement under the circumstances of social progress contains an element of deprecation because Utopian clearness leaves no scope to engage either a botanist (as was the case in A Modern Utopia) or a social scientist. Perhaps even Wells, who aptly combined the two properties, would have been overwhelmed by such an environment on a first encounter, because the culmination of clearness is likely to trigger processes contrary to progress. Earlier in The Time Machine, Wells demonstrated that a transformation into a deficient Eloi species could proceed from intellectual and physical degeneration after certain vital stimuli had been removed and basic needs gratified: "The too-perfect security of the Upperworlders had led them to a slow movement of degeneration, to a general dwindling in size, strength, and intelligence" (Wells 2010: 44). Therefore in Men Like Gods, the reminders of turmoil, anxieties, and swallows serve to fill in these Utopian absences with at least a modicum of the human condition as it was known in England.

\section{UTOPIA AND THE CRYSTAL PALACE}

The spatial continuity between England and Utopia lends itself to further analysis in the light of Wells's attitude to clearness, which surfaces in Men Like Gods and is linked with debates outside of the novel. Sydenham, like Slough, is another site which the protagonist passes by before his arrival in Utopia. Barnstaple's car "live[s] in a shed" (Wells 1923: 9), and the office of the newspaper he is working for is situated there. Besides, he feels contented "so long as his back was generally towards Sydenham" (Wells 1923: 13). By referring to "the domesticities of Sydenham" (Wells 1923: 208), Barnstaple deflates the importance of the area boasting in the period of 1851-1936 a glass and castiron Crystal Palace. Even though the Crystal Palace is not directly mentioned in the novel, 
there is little doubt about Wells's, as well as Barnstaple's, awareness of its presence on Sydenham Hill. In his Experiment in Autobiography (1934), Wells recalls only "the gardens of the Crystal Palace at Sydenham", through which he would take strolls as a teenager (Wells 1934: 97). The New Machiavelli (1911) contains a dubious rendering of the Crystal Palace both as an "immense facade" blocking the protagonist's way to school, and as a playground spectacle of "gratuitous fireworks" (Wells 2005: 44-45). Wells seemed to be casually dismissive of the Crystal Palace, even though its symbolism had spawned a whole range of implications for the concept of utopia and ideas of progress.

One such debate involved two nineteenth-century Russian writers who voiced their competing views on the Crystal Palace. In his revolutionary novel What Is to Be Done? (1863), Nikolay Chernyshevsky, reluctant to depict tragic situations at large, saw in the Crystal Palace the pinnacle of human aspirations for equality and rationality. In her fourth dream, the novel's protagonist Vera Pavlovna envisions people's happiness in the communality of their day-to-day labour and transparency of their living conditions concentrated in "a house of vast proportions" (Chernyshevsky 1982: 319). At the opposite end of this debate stood Fyodor Dostoyevsky, who visited the Crystal Palace in 1862 as part of his European tour and regarded it in eschatological terms. In his Winter Notes on Summer Impressions (1863), he recorded that "something final has been accomplished here - accomplished and completed. It is a biblical sight, ...some prophecy out of the Apocalypse being fulfilled before your own eyes" (Dostoyevsky 2008: 50). Dostoyevsky took up the subject anew in Notes from Underground (1864), where the protagonist fails to reconcile the Crystal Palace with the innermost needs and inclinations of human nature: "suffering is doubt, it is negation, and what good is a crystal palace in which one can have doubts? ...man will never renounce suffering, that is, destruction and chaos" (Dostoyevsky 2006: 34). For Dostoyevsky, the Crystal Palace came to represent a finality dissonant with man's baseness, which could only be rectified by relying on an external moral authority.

A few decades later the debate about the Crystal Palace attained fictional shape in Yevgeny Zamyatin's novel We (first published in English in 1924). In the wake of Chernyshevsky's vision, a whole state is accommodated in glass buildings, has names replaced with numbers and is drilled not to question the regular pattern of life and labour. On the surface, it may appear that Zamyatin toes Dostoyevsky's line in allowing the Mephi, who stand for natural human forces from "the other side of the Wall" (Zamyatin 1993: 217), to stoke up an "infinite revolution" against the allegedly stifling entropy of the One State (Zamyatin 1993: 221). However, as Roger Cockrell sums up, in accordance with Dostoyevsky's contention that "freedom is only meaningful if it is bounded by a system of absolute moral values" (Cockrell 2005: 86), Zamyatin stopped half-way between rejecting the Crystal Palace and fully realizing the outcome of this action. A great admirer of Wells's fiction and thought, Zamyatin paid him tribute in his pamphlet Herbert Wells (1922), which tended to trace his own dismissal of stagnation back to Wells (Cockrell 2005: 86).

Men Like Gods offers several indications of Wells's anti-entropic stance which help to clarify his attitude to the Crystal Palace and, furthermore, to the question of national identity. The fact that the Crystal Palace was left perhaps intentionally unnoticed in the novel testifies to the irrelevance of its image to the idea of Utopia elaborated by Wells. First of all, based on the fundamental principle of progress, Utopia, as one of the 
characters spells out, knows no rest: "Every day men and women awake and say: What new thing shall we do today? What shall we change?" (Wells 1923: 238). The origins of Utopia's self-styled progressive identity can be discovered in Wells's A Modern Utopia, drawing a distinction between the static and kinetic types of utopia. Acknowledging the paramount role of Darwinian evolutionism in mankind's intellectual history, Wells interpreted static utopias as "a balance of happiness won for ever against the forces of unrest and disorder that inhere in things" (Wells 1967: 5). Kinetic utopias, on the contrary, "must shape not as a permanent state but as a hopeful stage, leading to a long ascent of stages" (Wells 1967: 5). By extension, Wells prescribed uncertainty and even disease to Utopia whose progress ought to exclude stagnation and degeneration.

Secondly, Wells's Utopia reserves a niche for dissidence. As a witness to an expanding victory over nature and over man's natural predispositions, Barnstaple comes into contact with Utopia's "educational failure". Having lost her husband and sons in an accident at sea, Lychnis reverses from unemotional and steely rationality to more human passions of the heart: "She had rediscovered the lost passion of pity, first pity for herself and then a desire to pity others. She took no interest any more in vigorous and complete people..." (Wells 1923: 266). The misery of "the Age of Confusion", recounted to her by Barnstaple, kindles Lychnis's imagination just as the unnatural substitution of politeness for sympathy in Utopia does not appeal to her. To use Zamyatin's metaphor, Lychnis's "disease", which equals the discovery of the soul (Zamyatin 1993: 220), may be said to bear the hallmarks of Dostoyevsky's Underground Man, whose outbursts against the inhumanity of the Crystal Palace strike a very similar if louder chord. Left to her own "failed" devices, Lychnis enjoys an ambiguous position in the Utopian society. on the one hand, her reversion to the basic sentiment of pity discloses a glitch in the system of education in particular and in the line of progress at large. Even under the circumstances of a highly advanced civilization, the call of nature may reassert itself in human beings and cause an emotional transformation. On the other, this case of individual change can be taken as an auspicious caveat to the flaws of education that call for improvement in order to prevent future failures from happening, or at least to know how to handle them.

Lychnis's character fractures the stasis of the potential impeccability of Utopian clearness and contributes to the kinetic direction of Utopia's progress. Unlike the Mephi from Zamyatin's We, Lychnis barely presents a serious threat to Utopia because of her seeming solitariness. However, Lychnis is also reported to seek "her healing in healing" others (Wells 1923: 266). Her increasing interests in soul-doctoring may easily be wasted in the extremely rational society she belongs to. But a possibility of attracting a larger following of naturally inclined Mephi-like creatures cannot be discounted either. While Men Like Gods does not herald the latter development, A Modern Utopia stipulates "purging" socially maladjusted individuals into "islands of exile" (Wells 1967: 147). The islands will primarily accommodate "incurable cheats" who have failed to abide by the Utopian code of satisfactory earnings and social status, necessary for the conception of children (Wells 1967: 144). By exiling culprits from the civilized society, Wells places a premium on segregation, instead of effacement or torture. Thus, the image of the Crystal Palace is written out of Men Like Gods due to its entropic overtones which were intolerable to Wells. Inspired by his stay in Utopia, Barnstaple emerges as an advocate 
of the Great Revolution, whose principles differ from Zamyatin's "infinite revolution" in the distribution of forces. Unlike the One State, Utopia possesses self-regenerative elements derived from the licensed outlets for dissidence within its space. Therefore the renewal of Utopia may draw on the continuous overcoming of recurrent failures rather than on releasing natural forces in destructive action.

\section{CONCLUSION}

In the course of discussion, this paper has revealed ascertainable equivalences of the English and Utopian identities in terms of imaginary topography, rejection of the Crystal Palace as a symbol of stagnation and degeneration, and outlets for dissidence. Having demonstrated the limitations of clearness and the necessity of dissent in the construction of Utopia, Wells proceeded with an "awakening to Cosmopolis" in England. Equipped with the means of locomotion, traditions of freedom, and the discourse of "progress with continuity", the English identity appeared to be appropriately geared to a continuous transition into Utopia. On the figurative level, "progress with continuity" also concerned England's national symbol - the rose, which had developed into a double-petal flower in Utopia. The exit from Utopia was to be marked with the rose, which Barnstaple had intended to save as a keepsake; he "tore a single petal from the glowing bloom, and then laid down the rest of the great flower carefully in the very centre of his track" (Wells 1922: 296). Thus, the rose was designated to link the two spaces into one successive progression, serving as a sort of a "door in the wall" which might potentially lead into "another and altogether more beautiful world" (Wells 2007: 28). The envisioned extinction of this flower in Utopia, as well as its likely shrivelling in contemporary England, could equally disappoint the protagonist who would rather preserve the spatial continuity of a journey from England to Utopia.

\section{REFERENCES}

Bunyan, J. 2008. The Pilgrim's Progress. St. Ives: Penguin Books.

Chernyshevsky, N. 1982. What Is to Be Done: Tales about New People, transl. by Benjamin R. Tucker. London: Virago.

Cockrell, R. 2005. Future Perfect: H. G. Wells and Bolshevik Russia, 1917-32. In P. Parrinder and J. S. Partington (eds.) The Reception of H. G. Wells in Europe. London: Thoemmes Continuum, 74-90.

Dostoyevsky, F. 2006. Notes from Underground, transl. by Richard Pevear and Larissa Volokhonsky. London: Vintage Books.

Dostoyevsky, F. 2008. Winter Notes on Summer Impressions, transl. by Kyril FitzLyon. Richmond: Oneworld.

Gray, J. 2007. Black Mass: Apocalyptic Religion and the Death of Utopia. London: Allen Lane. Kupinse, W. 1999. Wasted Value: The Serial Logic of H. G. Wells's Tono-Bungay. Novel: A Forum on Fiction 33.1, 51-72.

Marcus, L. 2007. The Tenth Muse: Writing about Cinema in the Modernist Period. Oxford: OUP. 
Morris, W. 2003. News From Nowhere, or, An Epoch of Rest, Being Some Chapters from a Utopian Romance. Oxford: OUP.

Parrinder, P. 1970. H. G. Wells. Edinburgh: Oliver and Boyd.

Parrinder, P. 2006. Nation and Novel: The English Novel from Its Origins to the Present Day. Oxford: OUP.

Wells, H. G. 19--. In the Days of the Comet. London: W. Collins.

Wells, H. G. 1920. Ann Veronica. London: T. Fischer Unwin.

Wells, H. G. 1923. Men Like Gods. London: Cassell.

Wells, H. G. 1933. Mr. Britling Sees It Through. London: Waterlow and Sons.

Wells, H. G. 1934. Experiment in Autobiography: Discoveries and Conclusions of a Very Ordinary Brain (since 1866). London: Victor Gollancz and The Cresset Press.

Wells, H. G. 1967. A Modern Utopia. Lincoln: University of Nebraska Press.

Wells, H. G. 2005. The New Machiavelli, ed. by Simon J. James. St. Ives: Penguin Books.

Wells, H. G. 1975. The War of the Worlds. London: Pan Books.

Wells, H. G. 1982. The History of Mr Polly, Introduction by Frank Wells. London: Pan Books.

Wells, H. G. 2003. When the Sleeper Wakes. New York: The Modern Library.

Wells, H. G. 2007. The Door in the Wall. St. Ives: Penguin Books.

Wells, H. G. 2010. The Time Machine. In H. G. Wells: Classic Collection I. London: Gollancz, 1-84. Wells, H. G. 2010a. Tono-Bungay. London: Weidenfeld \& Nicholson.

Zamyatin, Ye. 1978. Herbert Wells. Letchworth: Prideaux Press.

Zamyatin, Ye. 1993. We, transl. by Clarence Brown. St. Ives: Penguin Books.

\section{SUMMARY}

\section{THE SPATIAL CONTINUATION OF ENGLISHNESS IN H. G. WELLS'S MEN LIKE GODS}

This paper examines continuities and ruptures between England and Utopia on the level of spatiality in H. G. Wells's Men Like Gods (1923). In designating the possibility of time travel, similar to The Time Machine, Wells enforces the idea of indiscrete space where Utopia has become England's spatial continuation. In line with Wells's bifocal perspective on England, which balances between a sentimental and yet detached depiction, and uncompromising visions of destruction, Utopia is construed of both clearness and dissent. Through the image of and debates about the Crystal Palace, it is sustained that the concept of Utopia is closely linked to Wells's anti-entropic impulses and evolutionary gradualism. It is concluded that, equipped with the means of locomotion, traditions of freedom, and the discourse of "progress with continuity", the English identity is appropriately geared to a continuous transition into Utopia.

KEYWORDS: utopia, England, Englishness, national identity, spatial continuity, entropy.

(Original scientific paper received 02.10.2011; revised 21.09.2012; accepted 21.09.2012) 